\title{
THE GENDER BASED STUDY ON THE TYPES OF SPEECH FUNCTIONS OF INSTRUCTORS IN CLASS
}

\section{Darajat RANGKUTI,}

Muslim Nusantara Al - Washliyah University, Medan, Indonesia

\section{Ummul Mawaddah RANGKUTI}

Muslim Nusantara Al - Washliyah University, Medan, Indonesia

\section{Darmina Eka Sari RANGKUTI}

Muslim Nusantara Al - Washliyah University, Medan, Indonesia

(C) The Author(s) 2019

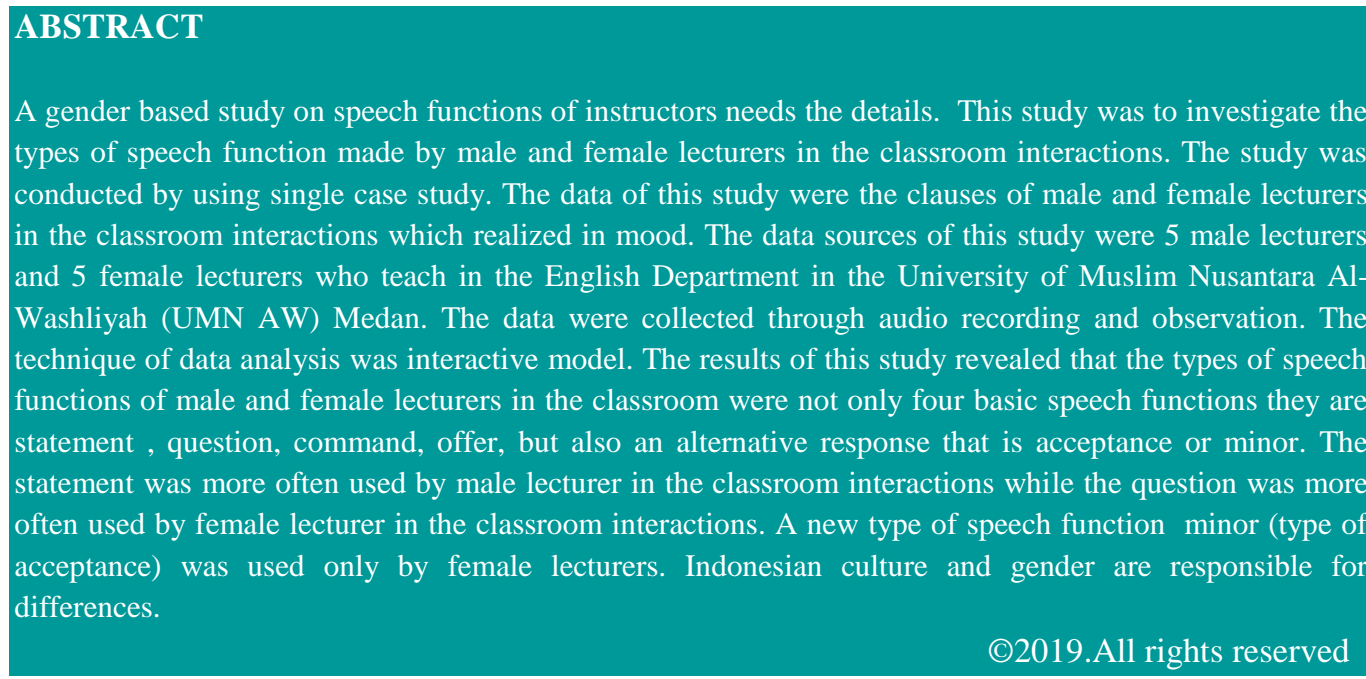

ARTICLE HISTORY

Received: 20/11/2018

Accepted: 17/02/2019

Published online: 01/04/2019

\section{KEYWORDS}

Speech functions, male and female lecturers, classroom interactions 


\section{Introduction}

Language has function to fulfill human needs in the exchange of experience, such as teaching learning process. Teaching learning process takes place mostly in classrooms and it is frequently carried out under the guidance and supervision of teachers or lecturers. The interaction between teachers or lecturers and students constitutes the most important part in all classroom activities. In addition, the appropriate speech functions of lecturers can create harmonious atmosphere and at the same time promotes a more friendly relationship between lecturers and students.

Speech functions is an action or performance done by language users such as asking, commanding and answering in order to fulfill the intention of the speakers and listeners (Ye ,2006; Nuyts and Auwera, 2016) states that. It is used as the medium exchange of their experiences. Speech function is more oriented to functional interpretation, especially systemic functional linguistics (SFL). It means that all the utterances involved the four types in speech functions (statement, question, offer, and command). Those have a semantic aspect which is realized by mood at the level of lexicogrammar (Martin,1992; Kohler, 2018). In this study, all the speech functions should be coded by three moods, namely declarative, interrogative, and imperative. All of these are the representations of human beings utterances in their communication. Therefore, speech function is used to exchange human's experiences through language function by using interpersonal function and coded by mood.

Modality specifies if the speaker is expressing his judgment or making a prediction. (Halliday, 2014; Nuyts and Auwera, 2016). The interpersonal function is realized at two levels namely at the level of (discourse) semantics and lexicogrammar. At the level of semantics, human being performs two roles namely Giving and Demanding. The commodity exchange may be either information or Goods \& Services. When the roles and commodities are cross classified, four specific activities or speech functions are derived. Based on Halliday (2014) states that speech functions are realized in four types, namely: statement, question, offer and command. Thompson (2010) emphasizes the important point that use of language lies at the very heart of social life. In general, it is noted that communication and language are important components of social life. Expressing thought and felling, conveying ideas, making request giving command, and so on.

Yuliati (2015) examined interpersonal meaning negotiation in the teacher-student verbal interaction. Most of the utterances produced by the teacher were in the form of command which means that the authority of the teacher was dominant. However, the teacher also tried to be equal with the students by using some declarative and interrogative types of mood. These made the students respond well but not really 
elaborated her/his responses. Ayoola (2013) found an interpersonal metafunction analysis of some selected political advertisements in some nigerian newspapers had the differences in the distribution of mood types in the adverts of the two political parties as well as their interpersonal meanings are determined by contextual factors such as the need to reflect the economic and socio-political context/situation of the country. In addition, Fikri (2015) found that there are some differences of male and female teacher talk in selecting Mood system in expressing interpersonal meaning to the students i.e. in giving information, in asking a question, in demanding the students to do something, and in offering something to the students. Cultural and social factor of the teachers are believed as the contributions to the differences.

In order to undergo this research, the data were taken from male and female lecturers of Universitas Muslim Nusantara Al-Washliyah, Medan. By adapting this theory the researcher took several utterances from one male lecturer and one female at English Department. This study focused on their utterances produced by male and female lecturer at Universitas Muslim Nusantara Al-Washliyah, Medan while teaching in the classroom.

Therefore, this study was aimed to identify the speech functions of male and female lecturers in the classroom interactions at Universitas Muslim Nusantara AlWashliyah, Medan.

\section{Theory of Speech Function}

Speech function is an action or performance one by language user such as: asking, commanding and answering in order to fulfill the intention of the speakers and listeners (Haliday and Matthiessen, 2014; Kohler, 2018). Speech function is used as the medium to exchange their experiences. Speech function is more oriented to unctional interpretation, specifically systemic functional, which means that all the utterances uttered the four types of speech functions. the four primary speech functions, see in the Table 1.

Table 1. Speech Functions by Halliday \& Matthiessen (2014)

\begin{tabular}{lll}
\hline & Commodity & \\
\hline Role & Information & Good \& Services \\
\hline Giving & Statement & Offer \\
\hline Demanding & Question & Command \\
\hline
\end{tabular}




\section{Gender in Language}

Gender is different from other forms of social inequality in that men and women interact extensively within families and households and in other role relations (Ridgeway \& Smith-Lovin, 1999). Gender refers to values, rights and reponsibility socially and culturally given to someone due to or as the consequences of the fact that $\mathrm{s} /$ he is male or female. This is to say that it is the society that makes someone masculine or feminine with rights and responsibillity attached to each status. In other words, whenever we meet a person, the first thing that comes to one's mind is whether the person is male or female, and accordingly, the person interprets in terms of gender. For instance, one may prefer men to occupy high and authoritative positions, and relate women to lower and subordinate roles or activities. Consequently, people are socialized according to the gender knowledge which influences our thinking and perception about the other, thinking of others in terms of gender is almost inescapable (Wareing, 2004).

As stated above, the differences between the sexes can be noticed at the level of social, cultural, religious, economic, and political spheres, and also at the level of language. Concerning language, males and females may adopt different characteristic when speaking to each other.

\section{Male and Female Teacher in the Classroom Interactions}

Many definitions of teacher language have been given from different perspectives. One definition goes that teacher language is the language in the classroom that takes up a major portion of class time employed to give directions, explain activities and check students' understanding (Sinclair\& Brazil, 1982). As an indispensable part of foreign language teaching, teacher language has its own features in that both the content and the medium are the target language. The language employed by teachers in language classes is served as the source of input of language knowledge, and also used to instruct language communication and organize classroom activities. Moreover, teacher language plays a very important role in the teaching process as an interactive device. For teachers would employ a lot of interactive devices such as repetition, prompting, prodding, and expansions, which would be evoking more interactions between teachers and students.

\section{Research Design}

This study was conducted by using a single case study research design. Case study research is a qualitative approach in which the investigator explores a bounded system (a case) or multiple bounded systems (cases) over time, through detailed, indepth data collection involving multiple sources of information (observations, interviews, audiovisual material and documents and reports) and report a case of description and case-based theme (Creswell, 2007:73). Thus, a case study research 
involves the study of an issue explored through one or more cases within a bounded system (setting and context).

\section{Findings and Discussions}

After analyzing the data, the data are classified based on the types of speech functions. There are four types of speech functions of male and female lecturers and one new type that have been found in the classroom interactions. They are statement, question, command, offer and minor, see in Table 2.

Table 2. Types of Speech Functions of Male and Female Lecturers in the Classroom Interactions

\begin{tabular}{|c|c|c|c|c|}
\hline $\begin{array}{l}\text { Speech } \\
\text { Functions }\end{array}$ & $\begin{array}{l}\text { Clauses of } \\
\text { ML's } \\
\text { Utterances }\end{array}$ & Percentage & $\begin{array}{l}\text { Clauses of FL's } \\
\text { Utterances }\end{array}$ & Percentage \\
\hline Statement & 97 & 77.60 & 78 & 38.80 \\
\hline Question & 19 & 15.20 & 90 & 44.77 \\
\hline Command & 7 & 5.60 & 25 & 12.43 \\
\hline Offer & 2 & 1.60 & 4 & 2.00 \\
\hline Minor & - & - & 4 & 2.00 \\
\hline Total & 125 & 100 & 201 & 100 \\
\hline
\end{tabular}

Based on Table 2 above it can be seen that, the types of speech functions that have been found from male lecturer in the classroom were statement, question, command, offer, and minor of response (acceptance). The male lecturer have produced the statement were $97(77.60 \%)$ so that it can be categorized as usually, while question were $19(15.20 \%)$ that can be categorized as often, command were $7(5.60 \%)$ that can be categorized as sometimes, offer were $2(1.60 \%)$ that can be categorized as rarely.

Furthermore speech functions of female lecturer found in the classroom were statement, question, command, offer, and minor of response. The female lecturer have produced the statement were $78(38.80 \%)$ so that it can be categorized as often, while question were $90(44.77 \%)$ that can be categorized as usually, command were 25 $(12.43 \%)$ that can be categorized as sometimes, offer were $4(2.00 \%)$ that can be categorized as rarely then minor were $4(2.00 \%)$ that can be categorized as rarely.

Based on the table, all types of speech functions occurred in the classroom interactions. It was also found a new type of speech function that is minor of response (acceptance). Minor of response (acceptance) was used only by female lecturers. Meanwhile, the dominant type of speech function which was used by male lecturer is statement. It was different from other research who did not find minor of response (type of acceptance) used by female educators. It happened because Indonesian female prefer 
doing small talk before teaching learning process. It indicates that culture and gender contributes to speech function influence.

\section{Statement}

The first type of speech function found in the classroom interaction used by male and female lecturers is statement. It can be seen and realized by declarative mood or often refers to statement clause which is matched with male and female lecturers in the classroom interactions. In other words, in categorizing statement in speech function, there are shared subject+finite that exist in male and female lecturer in the classroom. Statement clauses can be identified as clauses and realized by mood in which the structural element of subject occurs before the finite element of the clause. Here are some data that found based on the clauses of male and female lecturers' utterances:

\section{Male Lecturer:}

"This is very good information"

\begin{tabular}{|c|c|c|c|}
\hline This & Is & very good information & \multirow{3}{*}{$\begin{array}{l}\text { Statement is } \\
\text { realized by } \\
\text { Declarative Mood }\end{array}$} \\
\hline Subject & Finite & Compl. & \\
\hline Mood & & Residue & \\
\hline
\end{tabular}

This clause refers to statement which is realized by declarative mood. The word "this" means that "subject". It is said as the subject because it realizes the things by reference to which the proposition can be affirmed or denied or the item that is being held reponsible for the validity of the argument. Then the word "is" means that finite. It is the element that can be argued about. In relation to tense, it states that a proposition may become arguable through being located in time by reference to the speech event. This statement indicates that primary tense means past, present or future at the moment speaking. In this data, it indicates tense in present at the moment speaking. Moreover, the word "very good information" means that complement. It is said that as the complement because it is an element that has the potential for being given the interpersonally elevated status of modal responsibility. So that it can be concluded that declarative mood.

Female Lecturer:

"Our topic today is about English for tourism"

\begin{tabular}{|l|l|l|l|}
\hline $\begin{array}{l}\text { our topic } \\
\text { today }\end{array}$ & Is & about English for tourism & $\begin{array}{l}\text { Statement is } \\
\text { realized by } \\
\text { Declarative } \\
\text { Mood }\end{array}$ \\
\hline Subject & Finite & Complement & Residue \\
\hline Mood & &
\end{tabular}


Based on the clause of female lecturer it can be found that this clause is categorized as statement which is realized by declarative mood. Which is the word "our topic today" means that subject, it is said as the subject because it realizes the things by reference to which the proposition can be affirmed or denied or the item that is being held reponsible for the validity of the argument. Then, "is" means that finite, it is the element that brings the proposition down to earth, so that it is something that can be argued about. In relation to tense, it states that a proposition may become arguable through being located in time by reference to the speech event. This statement indicates that primary tense means past, present or future at the moment speaking, in this case it indicates tense in present at the moment speaking. After that, "about English for tourism" means as complement which is can be concluded that as statement which is realized by declarative mood. It is said that as the complement because it is an element that has the potential for being given the interpersonally elevated status of modal responsibility. Based on the data above, it can be seen that statement which is realized by declarative mood is dominant types that occurred in expressing the language in the classroom that is used by male lecturer. While, question is dominant types made by female lecturer. In additional point, all of the statement clauses were initiated by male lecturer realized in declarative mood because he wanted to give information for the students. It is known that declarative mood was always shown by relationship between "subject + finite" which means that a subject that can be followed by finite.

\section{Question}

The second type of speech functions that found in the male and female lecturers in the classroom interactions of UMN Al-Washliyah Medan is question. Interrogative mood means that asking question. English offers two main structures for asking question: polar interrogatives (yes/no question) or wh interrogatives (question using who, what, which, when, where, why, how). Here some data that have been found as following:

\section{Male lecturer:}

"Do you get it?"

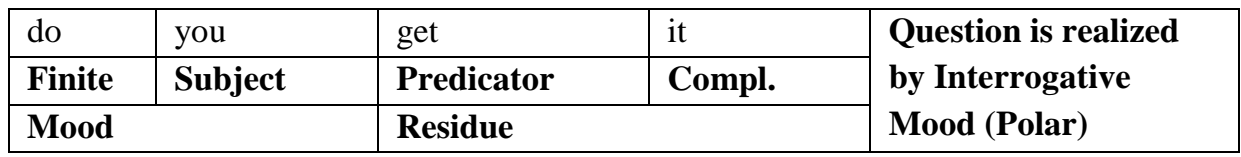

This clause refers to question which is realized by the polar interrogative mood. The structure of polar interrogative involves the positioning of the finite before the subject. It can be seen that the word "do" means that finite, it is the element that brings the proposition down to earth, so that it is something that can be argued about. In relation to tense, it states that a proposition may become arguable through being located in time by reference to the speech event. This statement indicates that primary tense means past, present or future at the moment speaking, in this case it indicates tense in 
asking at the moment speaking. Then "you" means that subject. it realizes the things by reference to which the proposition can be affirmed or denied or the item that is being held reponsible for the validity of the argument, after that the word "get" means that predicator. And the word "it" means complement. It can be seen as the interrogative mood.

\section{Female Lecturer:}

"Which one do you want to choose?"

\begin{tabular}{|c|c|c|c|c|}
\hline which one & Do & you & want to choose? & \multirow{3}{*}{$\begin{array}{l}\text { Question is realized } \\
\text { by Interrogative } \\
\text { Mood }(\mathrm{Wh})\end{array}$} \\
\hline Wh-question & Finite & Subject & Predicator & \\
\hline Res- & Mood & & -idue & \\
\hline
\end{tabular}

This clause refers to question which is realized by the wh-question interrogative mood. In wh-interrogative mood the present of a wh-element is needed to recognize, It may be conflated with either the subject. the cormplernent, or circumstatial adjunt, and it is shown as a constituent of mood or residue according to the status of the element with which it is conflated. The lecturer used interrogative sentence in a question sentences because she wanted to ask something the student. In this data, it can be seen that the word "which one" means that wh-question. Then, the word "you" means that subject, after that the word "do" means that finite, then "want to choose" means that predicator. So that it also concluded that is question realized by interrogative mood.

\section{Command}

The third types of speech functions that found in male and female lecturers in the classroom that is command which is realized by imperative mood. But this type is rarely used by male lecturer in the classroom. Meanwhile, this type is sometimes used by female lecturer in the classroom. This type contradicts with theory of Lakoff (1975) which states that men and women speak differently, women talk more than men, women break the rules of turn-taking less than men, women's speech is less direct or assertive than men.

Command which is realized by imperative mood means a verb form which makes a command or a request. Imperative clauses may have a mood element consisting of finite plus subject; or one consisting of finite only or subject only; or no mood element at all. Here some clauses that have been found as the following:

\section{Male Lecturer:}

"Understand that!" 


\begin{tabular}{|c|c|c|}
\hline Understand & that & \multirow{3}{*}{$\begin{array}{l}\text { Command } \\
\text { realized } \\
\text { Imperative } \\
\text { Mood }\end{array}$} \\
\hline Predicator & Complement & \\
\hline Residue & & \\
\hline
\end{tabular}

This clause means command which is realized by imperative mood. That just consists of predicator and compliment. It can be seen that "understand" means that predicator, it said as the predicator because it is realized by a verbal group. Then, "that" means that compliment. Because it is an element that has the potential for being given the interpersonally elevated status of modal responsibility. And also it is possible to become subject. So that it can be concluded that it is said command which is realized by imperative mood.

Female Lecturer:

"Come on!"

\begin{tabular}{|l|l|}
\hline come on & $\begin{array}{l}\text { Command is realized } \\
\text { by Imperative Mood }\end{array}$ \\
\cline { 1 - 1 } Predicator & \\
\hline
\end{tabular}

This clause means command which is realized by imperative mood. That just consists of predicator. For commands both the subject and the finite may be omitted. It can be seen that "come on" means that predicator, it said as the predicator because it is realized by a verbal group. Then, it can be concluded that it is said command which realized by imperative mood.

\section{Offer}

The fourth types of speech functions that found in male and female lecturers in the classroom that is offer, no unmarked realization of offer. It can be realized by either one of the moods. It can be declarative mood, interrogative mood and imperative mood. But this type is rarely used by male and female lecturers in the classroom interactions. Here some clauses that have been found as the following:

\section{Male Lecturer:}

"I will tell you the fact"

\begin{tabular}{|c|c|c|c|c|c|}
\hline $\mathrm{i}$ & Will & tell & you & the fact & \multirow{3}{*}{$\begin{array}{ll}\text { Offer } & \text { is realized } \\
\text { by } & \text { Declarative } \\
\text { Mood } & \end{array}$} \\
\hline Subject & Finite & Predicator & Compl. & Compl. & \\
\hline Mood & & Residue & & & \\
\hline
\end{tabular}

This clause means offer which is realized by declarative mood. Offer is as the initiation of the lecturer. He used it because he gave the good and services for the students. So that, it can be concluded that it is said offer which is realized by declarative mood. 
Female Lecturer:

"It will give you alternative destination for field trip"

\begin{tabular}{|l|l|l|l|l|l|}
\hline it & will & give & you & $\begin{array}{l}\text { alternative destination } \\
\text { for field trip }\end{array}$ & $\begin{array}{l}\text { Offer is realized by } \\
\text { Declarative Mood }\end{array}$ \\
\cline { 1 - 3 } & Finite & Predicator & Compl. & Compl. & \\
\hline Mood & Residue & \\
\hline
\end{tabular}

This clause means offer which is realized by declarative mood. It can be seen that "it" means that subject. It is said as the subject because it realizes the things by reference to which the proposition can be affirmed or denied or the item that is being held reponsible for the validity of the argument. Then "will" means that finite. Then, the offer is as the initiation of the lecturer. She used it because she gave the good and services for the students. So that, it can be concluded that it is said offer which is realized by declarative mood.

\section{Minor}

The fifth types of speech functions that found in male and female lecturers in the classroom interactions, that is minor which is realized by minor too. Here some clauses that have been found as the following:

\section{Male Lecturer:}

"Oke, good afternoon everyone"

\section{Female Lecturer:}

"Oke, good afternoon"

Minor was initiated by the lecturers. The lecturers used it because they greeted. Minor speech function is a fragmental, elliptical, or incomplete sentence or clause that still conveys meaning. Minor speech functions have the same function, i.e used to respond greeting. Within negotiation, minor generally encode following up reactions, that is contributions which do not have full negotiation status. The expression of exclamations, calls, greetings and alarms also can be found in the classroom interactions. So, that is why minor is realized by minor. Based on the explanation above, it can be concluded that there some types of speech functions found in male and female lecturers in the classroom interactions of English Department of UMN Al-Washliyah Medan were statement, question, command, offer and minor. Then, statement is the dominant type of speech function which was used by male lecturer. Meanwhile question is the dominant type of speech function which was used by female lecturer. 


\section{Conclusions}

There are five types of speech functions that have been found in the male and female lecturers in the classroom interactions namely (1) statement, (2) question, (3) command, (4) and (5) minor. In this study, male lecturers produced statement is 97 clauses (74.04\%), question is 19 clauses $(14.50 \%)$, command is 7 clauses (5.34\%), offer is 2 clauses $(1.52 \%)$. The female lecturer produced the statement is 78 clauses $(38.80 \%)$, question is 90 clauses $(44.77 \%)$, command is 25 clauses $(12.43 \%)$, offer is 4 clauses $(1.99 \%)$ and minor is 4 clauses (1.99\%). In addition, based on speech function used by female lecturers, it can be seen that the way of teacher in Indonesia has difference.

For the reader and the other researchers, it is suggested to get more understanding about speech functions it is important to get a lot theory and analyzing completely in doing research.

\section{Disclosure statement}

No potential conflict of interest was reported by the authors.

\section{Contact Information}

E-mail: darmina@yahoo.com 


\section{References and notes:}

Ayoola, \& Olusanya, M. (2013). An Interpersonal Metafunction Analysis of Some Selected Political Advertisements in Some Nigerian Newspapers. International Journal of Humanities and Social Science. Vol. 3 No. 8.

Creswell, J. W. (2007). Five qualitative approaches to inquiry. Qualitative inquiry and research design: Choosing among five approaches, 2, pp.53-80.

Fikri, Z. (2015). Mood Structure analysis of teacher Talk in EFL Classroom: A Discourse Study Based on Systemic Functional Linguistic Theory. GaneC Swara. 9(1),pp. 86-95.

Halliday, M A K \& Matthiessen Christian M.I.M, 2014. Hallidays'Introduction to functional Grammar. $4^{\text {th }}$ Edition. London: Routledge.

Kohler, K. J. (2018). Communicative Functions and Linguistic Forms in Speech Interaction. ${ }^{\text {st }}$ Edition. United Kingdom: Cambridge University Press.

Lakof, R. (1975). Language and women's place. New York: Harper \& Row.

Miles, M. B., Huberman, A. M., \& Saldana, J. (2014). Qualitative data analysis 3rd Edition: Source book of Bew Methods. Baverly Hills: SAGE Publications Inc.

Martin, J. R. (1992). English text: System and structure. John Benjamins Publishing.

Nuyts, J \& Auwera, J. V. D. (2016). The Oxford Handbook of Modality and Mood. $1^{\text {st }}$ Edition. United Kingdom: Oxford University Press.

Ridgeway, C. L., \& Smith-Lovin, L. (1999). The gender system and interaction. Annual review of sociology, 25(1), pp.191-216.

Sinclair, J. M., \& Brazil, D. (1982). Teacher talk. Oxford University Press.

Thompson, N. (2010). Theorizing social work practice. Palgrave Macmillan.

Wareing, S. (2004). Language and gender. na.

Ye, J. (2006). Traditional and online support networks in the cross-cultural adaptation of Chinese international students in the United States. Journal of Computer-Mediated Communication, 11(3), pp.863-876.

Yuliati. (2015). Interpersonal Meaning Negotiation in the Teacher-Student Verbal Interaction. Indonesia : Semarang State University. 